\title{
THE INFLUENCE OF HUMAN RESOURCE DEVELOPMENT TOWARD THE OFFICIALS' PERFORMANCE: A STUDY AT MAYOR'S OFFICE OF AMBON, INDONESIA
}

\author{
Tanihatu Arthur Reinaldo*, Sahertian Olivia Laura \\ State Polytechnic of Ambon, Indonesia \\ ${ }^{*}$ E-mail: arthurtanihatu@yahoo.com
}

\begin{abstract}
The purpose of this study is to analyze the effect of formal education, education and training program, and empowerment of the officials' performance. This research is an explanatory research using quantitative approach. Data were collected through survey. Population in this research was the officials at Mayor's Office of Ambon with 96 people as the sample. Data were analyzed using multiple regressions with SPSS. The results showed that formal education, education and training program, and empowerment simultaneously had a significant effect on the officials' performance. Partial test results showed that both education and training program and empowerment had a significant effect on the officials' performance. The dominant variable affecting the officials' performance was education and training program. In addition, it was also found that education did not affect the performance of the officials.
\end{abstract}

\section{KEY WORDS}

Human resources, development, education, training program, empowerment, performance, officials.

The purpose of good governance in the implementation of regional autonomy leads to the realization of democratic, responsive, accountable governance and the performance improvement of government organizations in providing services to the community. The service of a public organization can be successful and high-performing in a flexible and dynamic environment. Organizational flexibility is a condition that takes the flexibility into consideration in its service practices which is reflected in an operational, structural and strategic capabilities hierarchy (Grant, 1996; Ansoff, 2007). Reliable human resources handle and run maximum service within a government organization.

Human resources are assets and play an important role in the organization. Humans are an important, varied and sometimes problematic source for some organizations to occupy higher or lower levels (Mathis and Jackson, 2006). Mathis and Jackson (2006) also state that human resources are seen as increasingly important factor for an organization success. Nowadays, many organizations realize that the "human" element in the organization can provide competitive advantage.

Human resources are the central factor in an organization. Thus, human resources are a vital tool in determining the success of an organization. Therefore, individuals within the organization need to be developed in order to improve knowledge, skill, and attitude change ability, which ultimately can improve the officials' performance of and the organization'sperformance as a whole.

Every government organization, both at the provincial and regional levels, requires the arrangement of human resources to enable the organization to operate systematically and efficiently. In fact, there are still many regional governments that have not developed a comprehensive human resource management system yet. Whereas, human resource management is important in the organization to respond correctly and appropriately toward changes in the external environment of the organization.

One of the important instruments to improve the officials' performance in an organization, in this case government organization especially at Mayor's Office of Ambon, is through human resource development. Human resources development can be done through formal education, education and training program, and the officials' empowerment. Formal 
education is one of the beneficial ways to improve the ability of the officials and ultimately can improve their performance ( $\mathrm{Ng}$ and Feldman, 2009). Other human resources development is through the implementation of education and training program. The education and training program is an effective way to improve individual technical skills (Khan et al., 2011) and can improve the officials' performance and productivity (Elnaga and Imran, 2013; Amin et al., 2013). In addition to formal education and education and training program, human resources development is done through empowerment of the officials. The officials' empowerment is done by giving the officials power and authority to innovate and to make decisions. Performance would be improved through the officials'authority in working and making decisions (Nzuve and Bakari, 2012; Chen, 2011; Fadzilah, 2006).

Mayor's Office of Ambon is an organization whose duties and functions serve the needs and interests of the community with the vision of "Advanced, independent, religious, sustainable and harmonious community-based Ambon". One of its missions is to organize and to improve the bureaucracy professionalism in public service. In implementing this mission, human resources development needs to be executed.

Regional Government of Ambon has implemented a new model of power structure and the design of the new Regional Financial Information System as stipulated in Government Regulation Number 56 Year 2005 and Minister of Home Affairs Number 13 Year 2006. The officials' behavioral factor in Ambon's SKPD (Regional Work Units) in accepting new system is related to the officials' adaptation and involvement in designing a new system. With the adaptation ability, the officials will strive maximally to adjust to changes in their work environment so that the system implementation process can be accepted. Thus, the development of human resources is necessary in the application of new systems utilizing information technology.

In addition, Presidential Working Unit for Development Control and Supervision (UKP4) has set Ambon as Open Governance city in 2012, in which one of the recommendations is the information technology approaches, including in the education sector. On October $25^{\text {th }}$, 2012, PT. Telkom Ambon held a socialization of Business Solution for Government (e-Gov) products for SKPD leaders in Ambon municipal government. The socialization of Telkom's products is important and strategic for the needs of information technology services that have been transformed into primary needs for all parties. Information technology services offered by PT. Telkom are very helpful for Ambon municipal government in running the administration. The purpose of this technology use is the efficiency and effectiveness of the officials to realize the excellent service of global competitiveness in accordance with the vision of the organization. With the development and implementation of information technology at Mayor's Office of Ambon, human resources was ready to face the challenges in using information technology.

Sulistiyani (2004) states human resources development, especially in government organizations, should be seen as a whole both in physically and mentally dimensions. To achieve and improve good performance, human resource development is conducted through formal education, education and training program, and the officials' empowerment. The above topics attract the author's interest in conducting research on "The Influence of Human Resource Development on the Officials' Performance" (Study At Ambon Mayor's Office), which aims to 1) identify the significant influence between education, education and training program, and empowerment of the officials' performance simultaneously; 2) recognize the partial significant influence between formal education, education and training program, and empowerment of the officials' performance; 3 ) identify the dominant variables affecting the officials performance.

The Study of Conceptual Theory and Framework. The officials' development is the process of improving the conceptual, technical and morale skills of the officials. Heneman et al. (1987) argues that development is the process of producing one's skills and gaining experience of success in his/her current job as well as future tasks. Armstrong (2003) states that the human resources development is behavioral changes through experience. The officials' development can be done through formal education (school), non-formal education (courses, training, upgrading) as well as informal education (self-study, work 
experience, etc.). The officials' development must be planned and directed, meaning that there is a plan to place the relevant officials to more appropriate position in accordance with the needs of the organization.

Education is a process and a series of activities that lead individuals to the possibility of understanding and developing the knowledge, skills, and thoughtful values which is not limited to the activities of a particular field but rather provides a broad insight into formulated, analyzed and solved issues. Leopold (2002) suggests that education is an activity aimed at developing the knowledge, skills, morale, and understanding required for all aspects of life and not knowledge and skills that are concerned only with a limited field of activity.

Bernardin and Russel (1993) states that training is an attempt to improve the officials' performance during the current tenure. Further, training is an activity designed to improve the officials' performance in the designated work. Sikula in Hasibuan (2005) argues that training is a short-term educational process using systematic and organized procedures, so that the operational officials learn technical knowledge and skills for a particular purpose. Dessler (2004) suggests that training refers to the methods used to provide new or old officials the skills they need to do the job.

Sulistiyani (2004) statesthat one of the possible human resource development strategies is to create democratic working conditions and to encourage individual creativity through the officials' empowerment activities. Officials' empowerment is giving the officials the opportunity to innovate and to create, granting the officials authority at work, and giving the officials authority and facility at decision-making. Officials' empowerment aims to provide opportunity and circumstance which encourage the officials' process of learning, creativity, innovation and courage to take decision and achieve results which in line with the expectations.

The definition of human resource development in this research is the development of the officials through formal education, education and training program, and the officials' empowerment to improve the officials' performance.

The hypotheses in this study are as follows:

$\mathrm{H}_{1}$ : Formal education, education and training program, and empowerment simultaneously have a positive and significant impact on the officials' performance;

$\mathrm{H}_{2}$ : Formal education has a positive and significant effect on the officials' performance;

$\mathrm{H}_{3}$ : Education and training program has a positive and significant effect on the officials' performance;

$\mathrm{H}_{4}$ : Officials' empowerment has a positive and significant effect on the officials' performance.

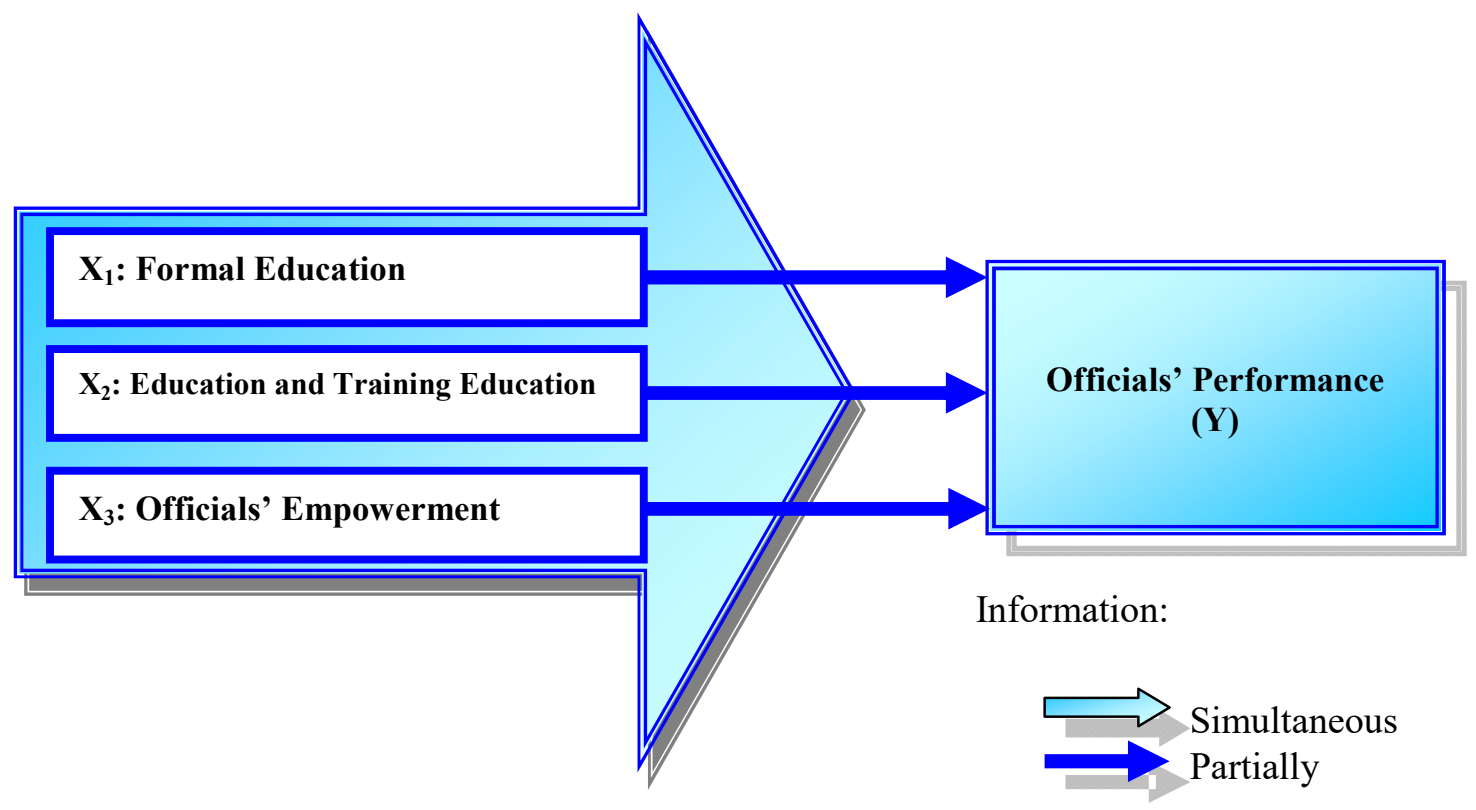

Figure 1 - Conceptual Framework 


\section{METHODS OF RESEARCH}

This research is explanatory research with survey approach. This study uses a quantitative approach because it explains the relationship between research variables through hypothesis testing and generally data are presented in the form of numbers calculated through statistical tests.

The study was conducted at the Ambon Mayor's Office. The populations of the study were the officials of SKPD at Mayor's Office of Ambon, with the total of 2546 people. Sampling used purposive sampling, in which the criteria used to determine the sample were: 1) the officials with civil servants status and not honorary status; 2) minimum education level of senior high school; 3) have followed the education and training program. Determination of the number of samples was based on the Slovin formula (Umar, 2001) with a precision of $10 \%$. As a result, the samples in this study were 96 respondents. The data used was"cross section" data. Data was collected through a questionnaire. Question items in this research were scored using Likert scale to measure the indicator. Thus, the variable wasconverted into a measurable indicator which could be used as a benchmark to create question items. Alternative answers consisted of 5 (five) alternative options having very low to very high levels ( 1 to 5 ) which were applied varies according to the question.

Indicators of the formal education variable were adapted from Heneman et al. (1981) with 3 items of questions, namely the implementation of study assignments for the officials', the relevance of the study program with the field of work, and the application of the study results at work. Indicators of education and training program were adapted from Handoko (2001) with 3 item statements, namely the effectiveness and efficiency of education and training programs, materials and facilities during education and training program, and the application of education and training outcomes at work. The officials' empowerment indicators were adapted from Sulistiyani (2004) with 5 items of questions, namely the officials' opportunity to innovate, the officials' opportunity to be creative, the officials' authorization in decision-making, the officials' authorization in completing the tasks, and available facilities for the officials to make decisions. Officials' performance indicators were adopted and adapted from Bernardin and Russel (1993) with 3 items of questions, consisting of the officials' work quality, the quantity of completed work, and punctuality in completing the work. Multiple regression analysis using SPSS software was used to test the hypothesis.

\section{RESULTS AND DISCUSSION}

Validity and Reliability Test. From the result of validity test, all question items had positive correlation value and was more than 0.5 (Hair et al., 2006). It meant that all instruments in this research were valid. Similarly, reliability test results showed that all variables had a coefficient value of Alpha Chronbach more than 0.6 (Hair et al., 2006; Sugiyono, 2003). All instruments used in this study were reliable.

Multicollinearity. This test aimed to test whether the correlation between independent variables were found in the regression model. A good regression model should not have a high or perfect correlation between independent variables. Based on the analysis, the results were tolerance $>0.1$ and Variance Inflation Factor $(\mathrm{VIF})<10$, showing that the data did not contain multicollinearity.

Heteroscedasticity. The heteroscedasticity test aimed to determine whether absolute residual variation was similar or not for all observations. If the assumption of non-occurrence of heteroscedasticitydid not met, then the estimator became no longer efficient in both small and large samples, Gujarati (1997). Comparison between significance coefficient and alpha levels can be performed to identify the heteroscedasticity (Sudarmanto, 2004). The significance value of each variable against the residual absolute was more than 0.05 . It meant that the regression equation hadhomoscedasticity or did not contain heteroscedasticity.

Normality. Normality test aimed to test the normality of the distribution of dependent variables and independent variables. Normality test data in the study was conducted by 
examining the distribution of normal or near normal data. Based on the analysis, the research data was normally distributed, because the value of a was more than 0.05 .

Multiple Regression Analysis. Multiple regression analysis was conducted by including the independent variable of Formal Education (X1), Education and Training Program (X2) and the Officials' Empowerment (X3) on the dependent variable of the Officials Performance (Y). Table 1 presents the result.

Table 1 - Regression Analysis

\begin{tabular}{|c|c|c|c|c|c|c|}
\hline Variable & $\begin{array}{c}\text { Regression } \\
\text { Coefficient }\end{array}$ & $\begin{array}{c}\text { Beta } \\
(\beta)\end{array}$ & $\begin{array}{c}\mathrm{T}- \\
\text { count }\end{array}$ & $\begin{array}{c}\text { Partial } \\
\text { Correlation }\end{array}$ & Significance & Information \\
\hline Formal education & .009 & .008 & 0.110 & -0.54 & .604 & $\begin{array}{c}\text { Not } \\
\text { Significant }\end{array}$ \\
\hline $\begin{array}{c}\text { Education and training } \\
\text { program }\end{array}$ & .502 & .424 & 4.281 & 0.409 & .000 & Significant \\
\hline $\begin{array}{c}\text { The officials' } \\
\text { empowerment }\end{array}$ & .276 & .375 & 3.781 & 0.346 & .001 & Significant \\
\hline \multicolumn{2}{|r|}{$\mathrm{R}=0,740 ; \mathrm{F}_{\text {table }}=2,70 ; \mathrm{R}^{2}=0,548 ; \mathrm{t}_{\text {table }}=1,660 ;$ Adjusted $\mathrm{R}^{2}=0,533 ; \mathrm{F}_{\text {count }}=37,145$} \\
\hline
\end{tabular}

Source: Result of Data.

Based on the above results, multiple linear regression equation could be made as follows:

$$
Y=\beta 1 \times 1+\beta 2 \times 2+\beta 3 \times 3
$$

$Y=0.008$ Formal Education +0.424 Education and Training Program +0.375 the Officials' Empowerment

In Table $1, \mathrm{R}$ value was 0.740 , indicating that the correlation between the independent variable $(\mathrm{X})$ to the dependent variable $(\mathrm{Y})$ was strong or close. The value of the adjusted determination coefficient (adjusted R2) of 0.548 meant that the independent variable (X) contributed to the dependent variable $(Y)$ of $54.8 \%$. The remaining contribution of $45.2 \%$ was explained by other variables which was not included in this research.

Hypothesis Testing:

Hypothesis 1: Formal education, education and training program, and empowerment simultaneously have a positive and significant effect on the officials' performance.

$F_{\text {count }}$ value of $37.145, F_{\text {table }}$ value of 2.70 , and $F_{\text {count }}(37.145)>F_{\text {table }}(2.70)$. Thus, in this study, $\mathrm{H} 0$ was rejected and $\mathrm{H} 1$ was accepted, meaning that simultaneously the three independent variables of formal education, education and training program, and the officials' empowerment as one had a significant influence on the officials' performance variables.

Hypothesis 2: Formal education has a positive and significant effect on the officials' performance.

The result of partial regression analysis between formal education on the officials' performance was $t_{\text {count }}=0,110>t_{\text {table }}=.1 .660$. Therefore, $\mathrm{H} 2$ was rejected, meaning that formal education variable had noeffect to the officials' performance variable.

Hypothesis 3: Education and training program have a positive and significant effect on the officials' performance.

Regression and partial analysis results between the variables of education and training program on the officials' performance variable was $t_{\text {count }}=4.281>t_{\text {table }}=1.660$. Thus, education and training program had a positive and significant effect on the officials' performance

Hypothesis 4: The officials' empowerment has a positive and significant effect on the officials' performance.

Result of regression and partial analysis between work environment variable (X3) to the officials' performance variable $(Y)$ was $t_{\text {count }}=3,781>t_{\text {table }}=.1 .660$, so $\mathrm{H} 4$ was accepted. It meant that the officials' empowerment had a positive and significant impact on the officials' performance. 
Based on the results of regression, the officials' empowerment has a dominant influence on the officials' performance variables. This can be seen from the highest $t_{\text {count }}$ value of $4.281, \beta$ value of 0.424 , and partial correlation value $(r)$ of 0.409 .

\section{DISCUSSION OF RESULTS}

The Influence of Formal Education on The officials Performance. Human resource development conducted at Mayor's Office of Ambon is through continuing formal education to the officials for higher education level, with the aim to improve intellectual ability, insight, and the officials' skill in achieving maximum officials' performance.

The findings of this study indicate that the implementation of formal education program had no effect in improving the officials' performance. Although human resources development through advanced formal education was developing three aspects of intelligence, namely the cognitive, affective and psychomotor intelligence, but in reality it did not affect the officials' performance. Formal education had no significant effect on the officials' performance, as it related to theofficials' need for technical issues related to the use of technology at work.

The results of this study are not in line with the research conducted by $\mathrm{Ng}$ and Feldman (2009), and Trianingsih dan Surani (2006), which states that formal education influences the improvement ofthe officials performance. The findings of this study are not in line with Flippo's (2002) statements who argue that formal education is important in improving the general knowledge of individuals as well as increasing mastery of theories and skills in decision-making on issues concerning activities to achieve goals. The results of this study are in line with research conducted by Lazim and Triyaningsih (2013) who also found that formal education has no effect on the officials' performance.

The Influence of Education and Training Program on the Officials' Performance. Besides through formal education, human resource development at Ambon's Mayor Office was conducted through education and training program in the form of practice-oriented shortterm education and training program to provide the officials knowledge about the techniques (skills) and expertise in a particular field of work. In terms of the relevance of the program material to the employment field, it was found that the relevance of education and training materials was greater than the relevance of the material in formal education program. This condition indicated that education and training programs were specially designed to provide specific knowledge and technical skills in accordance with the work the officials did, especially in the use of technology.

The results of this study indicated that education and training program had a positive and significant effect on the officials' performance, meaning that appropriate education and training program could improve the officials' performance. Education and training program had very dominant influence on the officials' performance. The results of research which stated that education and training program affected the performance of the officials' are in line with the findings of Kum et al. (2014), Khan et al. (2011), Elnaga and Imran (2013), Amin et al. (2013), Dartha (2010), Sinaga (2014), Trianingsih dan Surani (2006).

Implementation of education and training programs conducted by the Mayor Office of Ambon run well because the education and training program was done efficiently and effectively. The officials felt that the education and training program were efficient because the time was short enough so it did not disrupt their duties. Short-time program also made small-cost budget. The officials argued that education and training programs were effective because the goals or targets of education and training programs which were oriented to the delivery of material knowledge and technical skills were in accordance with their specific duties. Some weaknesses experienced by the officials during the implementation of this education and training program were inadequate facilities, very limited types of education and training program, and lack of equal opportunity for the officials to attend education and training program. Education and training program should not simply fulfill the formalities demands such as structural education and training program, functional education and training program, and technical education and training program, but rather those that are 
truly oriented towards the demands of professionalism and the officials' competence which are in line with their main tasks and functions.

The Influence of the Officials' Empowerment on the Officials' Performance. In addition to formal education and education and training program, human resources development undertaken to improve the officials' performance was through the officials' empowerment. The officials' empowerment was done through providing the officials opportunities to innovate and to create, granting authority at decision-making and granting authority and facility at work. The purpose of the officials' empowerment was to provide opportunities and conditions that encourage the learning process, creativity, innovation and courage the officials to make decisions and achieve results in accordance with expectations.

The results showed that the officials' empowerment had a significant effect on the officials' performance. The results of this study are in line with the theory which states that empowerment is an important tool to improve performance and increase organizational effectiveness, and empowerment is the concept of giving people more responsibility for what they do. Further, empowerment is a process to improve efficiency and make individuals produce greater contributions.

This finding is in line with research conducted by Nzuve dan Bakari (2012), Chen (2011), Fadzilah (2006), Isrorina and Setyowati (2009). The officials' were empowered and authorized by the leaders in making decisions.

The results of this study provide the theoretical and practical implications associated with the development of human resources. Theoretically, the development of human resources through the implementation of education and training program is very influential in improving the officials' performance. Proper education and training programs will be very useful for the officials to improve their ability to work. In addition, the officials' empowerment can also improve the officials' performance. The officials who are empowered in decisionmaking and are empowered effectively will show better performance.

\section{CONCLUSION AND RECOMMENDATIONS}

Based on the results of the analysis and discussion, human resources development consisting of advanced formal education, education and training program, and empowerment as one had a significant effect on the officials' performance. Education and training programs consisting of the effectiveness and efficiency of education and training activities, the relevance of the program to the work needs and the feasibility of educational and training facilities contributed greatly in improving the officials' performance at Mayor's Office of Ambon. The officials' empowerment, which consists of providing the officials opportunities to innovate and to create, authority in decision-making and providing authority and facilities to the officials at work also had an effect on improving the officials' performance. Formal education, which consists of the implementation of study assignments, the relevance of the study program with the field of work, and the application of study results at work, had no effect in improving the performance of the officials' at Mayor's Office of Ambon.

Research and data collection in this research was cross section, in which data was only taken in one particular time. This affected the findings of the research variables causality. Therefore, it is necessary to develop future research to use longitudinal study to study human resource development variable and the officials' performance.

Education and training program greatly affected the officials' performance. Therefore, the leaders at Mayor's Office of Ambon should implement appropriate education and training programs in accordance with the officials' needs, with adequate materials and facilities. In addition, the leaders should pay attention to the officials' empowerment through the authority to innovate, create and make decisions, so that the officials could apply their maximum skills and competencies. 


\section{REFERENCES}

1. Amin, A; R. Saeed; R. N. Lodhi; Mizna, Simra, A. Iqbal dan R. E. Tehreem. 2013. The Impact of Employees Training On the Job Performance in Education Sector of Pakistan. Middle-East Journal of Scientific Research. . Vol. 17 (9): 1273-1278

2. Ansoff, H.I. (2007). Strategic Management Classic, Palgrave Macmillan. Hampshire, UK. http://dx.doi.org/10.1057/9780230590601

3. Armstrong. M. 2003. Managing People. PT Gramedia. Jakarta.

4. Bernadin, H. John dan Russel, J.E.A., 1993. Humans Resource Management: an Experimental Approach. International Edition. Singapore. McGraw Hill.Inc

5. Chen, K. P. 2011. A Study on the Impact of Empowerment on Employee in the Automotive Industry in Malaysia. Unpublished Thesis. Open University Malaysia.

6. Dartha, I Ketut. 2010. Pengaruh Pendidikan dan Pelatihan (Diklat) Terhadap Kinerja Pegawai Negeri Sipil Pada Sekretariat Daerah Kota Malang. Jurnal Ekonomi Modernisasi. Vol. 6 (2): 140-160.

7. Dessler, Gary. 2004. Manajemen Sumber Daya Manusia. Jakarta: Prenhallindo.

8. Elnaga, Amir dan Amen Imran. 2013. The Effect of Training on Employee Performance. European Journal of Business and Management. Vol. 5 (4): 137-147.

9. Fadzilah, Ari. 2006. Analisis Pemberdayaan Karyawan dan Self of Efficacy Terhadap Kinerja Karyawan Bagian Penjualan (Studi Kasus pada PT. Sinar Sosro Wilayah Pemasaran Semarang. Jurnal Studi Manajemen dan Organisasi. Vol. 3 (1): 12-27.

10. Flippo, Edwin B. 2002 Manajemen Personalia, Jilid 1. Translated by M. Mas'ud. Jakarta: Penerbit Erlangga.

11. Grant, R. M. 1996. Toward a knowledge-based theory of the firm. Strategic Management Journal (17:Winter): 109-122.

12. Gujarati, Damodar. 1997. Ekonometrika Dasar. Translated by S. Zain. Jakarta: Erlangga.

13. Hair, Anderson, Tatham, Black. 2006. Multivariate Data Analysis. Fifth Edition. Prentice Hall. New Jersey.

14. Handoko, T Hani. 2001. Manajemen Personalia dan Sumberdaya Manusia. BPFE. Universitas Gajah Mada, Yogyakarta.

15. Hasibuan, Malayu S. P. 2003. Manajemen Sumber Daya Manusia. Edisi Revisi, Cetakan Keenam, Penerbit Bumi Aksara, Jakarta.

16. Heneman, R. L.; Wexley, K. N. and Moore, M. L. 1987. Performance rating accuracy: A critical review. Journal of Business Research. Vol. 15: 431-448.

17. Isrorina dan Widhy Setyowati. 2009. Pengaruh Pemberdayaan dan Karakteristik Pekerjaan Terhadap Kinerja Pegawai dengan Mediasi Iklim Organisasi pada Sekretariat Daerah Kabupaten Pekalongan. Tema. Vol. 6 (1): 19-31.

18. Khan, R.A.G; F.A. Khan dan A. M. Khan. 2011. Impact of Training and Development on Organizational Performance. Global Journal of Management and Business Research. Vol. 11 (7): 62-68.

19. Kum, F.D dan R. Cowden. 2014. The Impact of Training and Development on Employee Performance: A Case Study of Escon Consulting. Singaporean Journal of Busniess Economics Studies. Vol. 3 (3): 72-105.

20. Lazim, Mat dan S. L. Triyaningsih. 2013. Pengaruh Pendidikan Formal, Motivasi dan Pendidikan Pelatihan Terhadap Kinerja Petugas Pengawas di Lingkungan Balai Besar Wilayah Sungai Bengawan Solo. Jurnal Manajemen Sumberdaya Manusia. Vol. 7 (1): 24-35.

21. Leopold, J. 2002. Human Resources in Organisations. Prentice Hall. New York.

22. Mathis, Robert L. dan Jackson H. John 2006. Manajemen Sumber Daya Manusia, Salemba Empat. Jakarta.

23. Ng, Thomas. W.H dan Daniel C. Feldman. 2009. How Broadly Does Education Contribute to Job Performance?. Personel Psychology. Vol. 62: 89-134.

24. Nzuve, S. N. M dan T. H. Bakari. 2012. The Relationship Between Empowerment and Performance in the City Council of Nairobi. Problems of Management in the 21th Century. Vol. 5: 83-98. 
25. Sinaga, D. O. 2014. Pengaruh Pendidikan dan Pelatihan (Diklat) Terhadap Kinerja Pegawai di Dinas Cipta Karya, Permukiman dan Perumahan Kabupaten Kotabaru. Kindai. Vol. 10 (2): 114-125.

26. Sudarmanto, R. Gunawan. 2004. Analisis Regresi Linear Ganda dengan SPSS. Yogyakarta: Graha Ilmu.

27. Sugiyono. 2003. Stalistika Untuk Penelitian. Cetakan Kedua. Bandung: Ikatan Penerbit Indonesia.

28. Sulistyani, Ambar Teguh. 2004. Kemitraan dan Model-Model Pemberdayaan. Yogyakarta: Graha IImu.

29. Trianingsih, S. L dan G. Surani. 2006. Pengaruh Pendidikan Formal dan Pelatihan Terhadap Profesionalisme Kepala Sekolah Dasar. Jurnal Manajemen Sumber Daya Manusia. Vol. 1 (1): 49-62. 